\title{
Pollution Load Capacity Analysis of BOD, COD, and TSS in Karang Mumus River, Samarinda
}

\author{
Vita Pramaningsih ${ }^{1, *}$, Slamet Suprayogi ${ }^{2}$, and Ignasius Loyola Setyawan Purnama ${ }^{2}$ \\ ${ }^{1}$ Department of Environmental Health, Universitas Muhammadiyah Kalimantan Timur, \\ Jl. Ir. H. Juanda, No.15, Samarinda, East Kalimantan, Indonesia \\ ${ }^{2}$ Department of Environmental Geography, Faculty of Geography, Universitas Gadjah Mada, \\ Bulaksumur, Sekip Utara 55281, Yogyakarta, Indonesia
}

${ }^{*}$ Corresponding author:

email:vp799@umkt.ac.id

Received: March 19, 2019

Accepted: June 15, 2019

DOI: $10.22146 / \mathrm{ijc} .44296$

\begin{abstract}
The Rivers in Indonesia often accommodate pollution from all community activities. This happened due to a large number of people who use watersheds for living. One of those rivers is the Karang Mumus River in Samarinda City, East Kalimantan. This study aims to analyze the capacity of the Karang Mumus River pollution load in segments 2, 3 and 4. The analysis model used in this study was the QUAL2Kw and ArcGIS models. The former used to calculate the capacity of river pollution and the latter used to determine land use. The results of the QUAL2Kw Model analysis shown that the capacity of the BOD was exceeded in all segments, COD was exceeded in all segments except segment 3 . The entire segment had an allocation of sectoral pollution load originated from domestic activities. This study concluded that the dominant land use of settlements was one of the main causes of this problem.
\end{abstract}

Keywords: capacity load; BOD; COD; TSS; QUAL2Kw model

\section{- INTRODUCTION}

Karang Mumus River is located in Samarinda City, East Kalimantan, and is also a subsidiary river of the Mahakam River. The length of the river from upstream to downstream reaches $17 \mathrm{~km}$ with a width of $10-15 \mathrm{~m}$. This watershed had densely populated settlements. The majority of the population conducted bathing, washing, and toilet activities directly in this river, causing a lot of garbage thrown into the river and causing pollution. This condition was exacerbated by the existence of economic activities and traditional markets around the riverbanks. This worsened river water quality and affected public health. In addition, this also caused floods and pollution in rivers, household waste had also reduced the quality of water in this river.

Based on the ASPT and WQI, Karang Mumus River recently polluted with Chironomus sp. and Melanoides tuberculata as codominant taxa [1]. The contamination of PAHs in Karang Mumus River was relatively high because of polluted urban, suburban areas that a lot of commercial activity and residence [2]. Based on monitoring of water quality in Karang Mumus River in September 2015 held by Environment Agency (BLH) of Samarinda City, pH, BOD, COD, TSS, and Fecal Coliform at some points have exceeded the standard. These various studies were unsettling for the local government, and with various considerations PERDA East Kalimantan Province No. 2 of 2011 concluded that the Management of Water Quality and Water Pollution Control which states that the Karang Mumus River was classified as Class II meaning that the phosphate level in some river points was very high and dangerous.

Some earlier research mentioned several causes influencing the quality of river water, according to Effendy, the speed of river flow and various activities on the banks affected the quality of river water [3]. In line with this, according to Kalavaty, land use in upstream areas made the river water quality polluted [4]. Furthermore, in the rainy season, the flow of the river increased and caused pollution due to the increase in agricultural activities. These were the evidence of how

Vita Pramaningsih et al. 
the use of river water in the upstream areas will affect the water quality in the downstream [5]. There were also social factors such as industrialization, urbanization, and agriculture activities that also affected the river's water physically and chemically for $\mathrm{pH}$, TSS, BOD, COD, nitrate, and phosphorus parameters [6].

One attempt to make sure the level of pollution in the river is by using the Qual2Kw model. QUAL2Kw Model can be used to calculate the capacity of the pollution load according to the desired quality standard. The QUAL2Kw model was also used to determine the future river water quality, so the result of it can be used for the government's policy consideration [7]. The QUAL2Kw model was used to predict water quality in the next few years by calculating the projected population growth and sources of Point Source (PS) and Non Point Source (NPS) pollution [8]. The QUAL2Kw model is useful as a tool for simulating water quality in rivers and measuring the impact of NPS pollution from agriculture [9]. QUAl2 Kw can also be used to simulate DO, BOD, Total Coliform, and Total Nitrogen content in rivers for 10 years [10].

\section{- EXPERIMENTAL SECTION}

\section{Materials}

Sampling for water quality checks carried out by purposive sampling. Determination of the sampling time was done by considering the backwater of the Mahakam River using the information that can be accessed at http://pasanglaut.com, accessed March 1, 2016, and the conditions of the collection at the river mouth. Based on these considerations, 17 sampling points were determined, namely 10 points in tributaries and drainage, and 7 points were taken in the main river. Sampling was carried out from upstream to downstream without being influenced by the Mahakam River backwater. Location of sampling and division of river segments was presented in Table 1, while the map of sampling points was presented in Fig. 1.

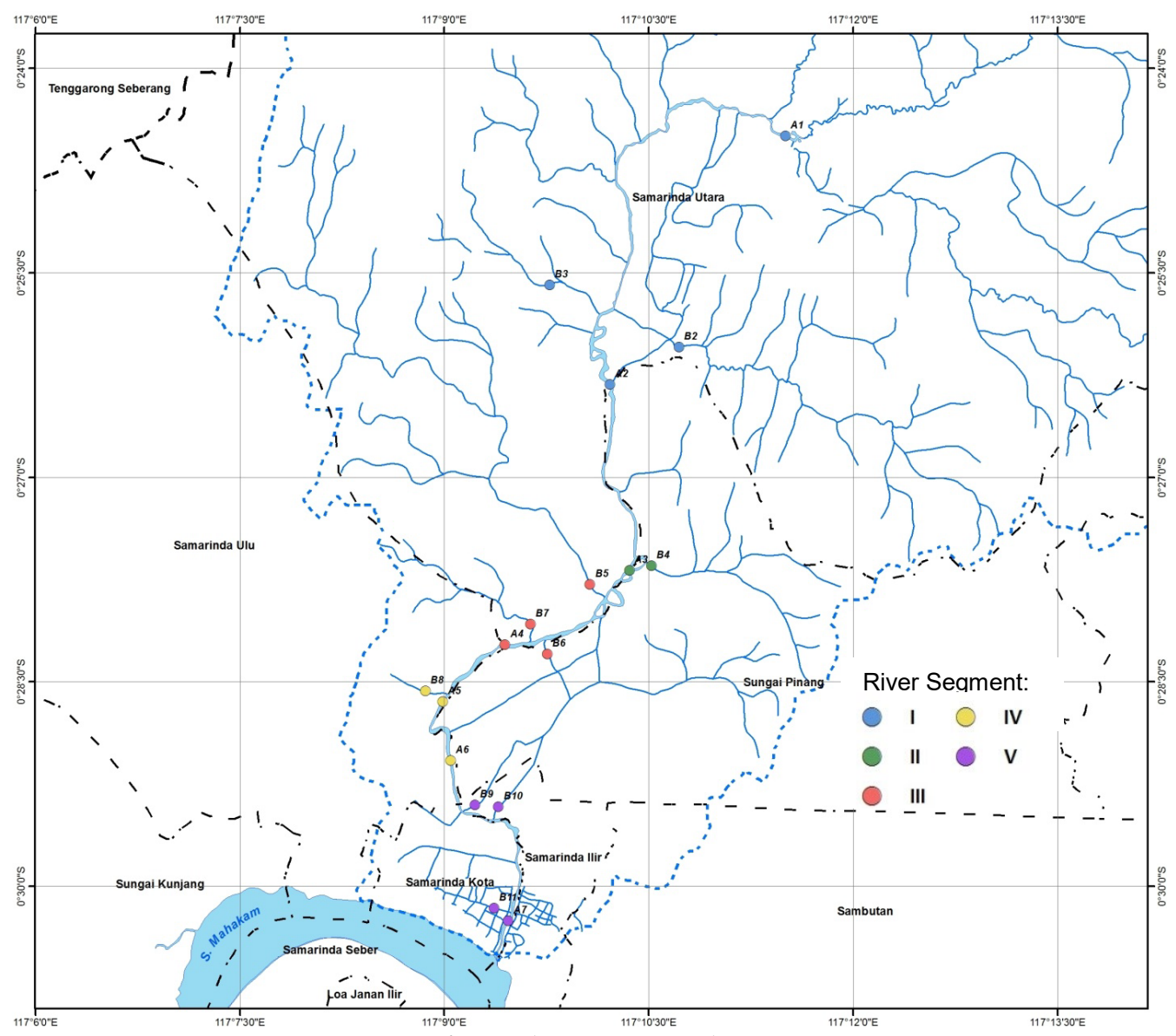

Fig 1. Map of sampling point and river segment 
Table 1. Sampling location and river segment of Karang Mumus River

\begin{tabular}{|c|c|c|c|c|c|c|c|}
\hline \multirow{2}{*}{ No. } & \multirow{2}{*}{ Location } & \multicolumn{2}{|c|}{ Coordinate } & \multirow{2}{*}{ Code } & \multirow{2}{*}{ Segment } & \multirow{2}{*}{$\begin{array}{l}\text { Long } \\
(\mathrm{km})\end{array}$} & \multirow{2}{*}{$\begin{array}{l}\text { Elevation } \\
(\mathrm{m})\end{array}$} \\
\hline & & E (Longitude) & S (Latitude) & & & & \\
\hline 1 & Bridge after Benanga Reservoir & $117^{\circ} 11^{\prime} 29.8357^{\prime \prime} \mathrm{BT}$ & $0^{\circ} 24^{\prime} 30.3840^{\prime \prime} \mathrm{LS}$ & A1 & \multirow{4}{*}{ I } & \multirow{4}{*}{6.36} & 11.647 \\
\hline 2 & Lempake Jaya River & $117^{\circ} 10^{\prime} 43.4605^{\prime \prime} \mathrm{BT}$ & $0^{\circ} 26^{\prime} 2.7887^{\prime \prime} \mathrm{LS}$ & $\mathrm{B} 2$ & & & 11.157 \\
\hline 3 & Bengkuring River & $117^{\circ} 09^{\prime} 46.7605^{\prime \prime} \mathrm{BT}$ & $0^{\circ} 25^{\prime} 39.8136^{\prime \prime} \mathrm{LS}$ & B3 & & & 11.210 \\
\hline 4 & Tepian Lempake Bridge & $117^{\circ} 10^{\prime} 13.0293^{\prime \prime} \mathrm{BT}$ & $0^{\circ} 26^{\prime} 19.0643^{\prime \prime} \mathrm{LS}$ & $\mathrm{A} 2$ & & & 10.870 \\
\hline 5 & Mugirejo-Gn. Lingai River & $117^{\circ} 10^{\prime} 30.6227^{\prime \prime} \mathrm{BT}$ & $0^{\circ} 27^{\prime} 39.4128^{\prime \prime} \mathrm{LS}$ & B4 & \multirow{2}{*}{ II } & \multirow{2}{*}{2.71} & 7.419 \\
\hline 6 & Gunung Lingai (Jl. P.M. Noor) & $117^{\circ} 10^{\prime} 23.9628^{\prime \prime} \mathrm{BT}$ & $0^{\circ} 27^{\prime} 36.8172^{\prime \prime} \mathrm{LS}$ & A3 & & & 6.792 \\
\hline 7 & Sempaja River & $117^{\circ} 10^{\prime} 4.8901^{\prime \prime} \mathrm{BT}$ & $0^{\circ} 27^{\prime} 47.1889^{\prime \prime} \mathrm{LS}$ & B5 & \multirow{4}{*}{ III } & \multirow{4}{*}{2.08} & 6.492 \\
\hline 8 & A. Yani (Gelatik-Pemuda) Drainage & $117^{\circ} 09^{\prime} 32.6305^{\prime \prime} \mathrm{BT}$ & $0^{\circ} 28^{\prime} 18.4117^{\prime \prime} \mathrm{LS}$ & B6 & & & 5.991 \\
\hline 9 & Pramuka-UNMUL River & $117^{\circ} 09^{\prime} 39.2113^{\prime \prime} \mathrm{BT}$ & $0^{\circ} 28^{\prime} 4.9043^{\prime \prime} \mathrm{LS}$ & B7 & & & 5.987 \\
\hline 10 & Gelatik Bridge & $117^{\circ} 09^{\prime} 26.7660^{\prime \prime} \mathrm{BT}$ & $0^{\circ} 28^{\prime} 13.7029^{\prime \prime} \mathrm{LS}$ & A4 & & & 5.624 \\
\hline 11 & Lembuswana-Vorvoo Drainage & $117^{\circ} 09^{\prime} 1.3679^{\prime \prime} \mathrm{BT}$ & $0^{\circ} 28^{\prime} 34.8815^{\prime \prime} \mathrm{LS}$ & B8 & \multirow{3}{*}{ IV } & \multirow{3}{*}{2.24} & 5.49 \\
\hline 12 & S. Parman Bridge & $117^{\circ} 09^{\prime} 2.9383^{\prime \prime} \mathrm{BT}$ & $0^{\circ} 28^{\prime} 35.8637^{\prime \prime} \mathrm{LS}$ & A5 & & & 5.39 \\
\hline 13 & Perniagaan Bridge & $117^{\circ} 09^{\prime} 3.4849^{\prime \prime} \mathrm{BT}$ & $0^{\circ} 29^{\prime} 4.5095^{\prime \prime} \mathrm{LS}$ & A6 & & & 5.16 \\
\hline 14 & Jl. Gatot Subroto Drainage & $117^{\circ} 09^{\prime} 10.1457^{\prime \prime} \mathrm{BT}$ & $0^{\circ} 29^{\prime} 27.6665^{\prime \prime} \mathrm{LS}$ & B9 & \multirow{4}{*}{$\mathrm{V}$} & \multirow{4}{*}{3.36} & 4.90 \\
\hline 15 & Jl. Lambung Mangkurat Drainage & $117^{\circ} 09^{\prime} 21.6432^{\prime \prime} \mathrm{BT}$ & $0^{\circ} 29^{\prime} 31.4340^{\prime \prime} \mathrm{LS}$ & $\mathrm{B} 10$ & & & 4.56 \\
\hline 16 & P. Hidayatullah Drainage & $117^{\circ} 09^{\prime} 29.4943^{\prime \prime} \mathrm{BT}$ & $0^{\circ} 30^{\prime} 10.0386^{\prime \prime} \mathrm{LS}$ & B11 & & & 4.19 \\
\hline 17 & Sei Dama Bridge & $117^{\circ} 09^{\prime} 31.1835^{\prime \prime} \mathrm{BT}$ & $0^{\circ} 30^{\prime} 10.6989 " \mathrm{LS}$ & A7 & & & 3.96 \\
\hline
\end{tabular}

A = Main River/Karang Mumus River

$\mathrm{B}=$ Tributary and Drainage

\section{Instrumentation}

Sample from the 17 point location is analyzed in the laboratory for BOD, COD, and TSS parameter. Analysis results were used as the input in the QUAL2Kw Model to determine the load capacity of the pollution of the river in each parameter. The modeling simulated two scenarios, namely, the scenario I in existing conditions and scenario II as a capacity load of pollution based on the standard of the Regulation Province East Kalimantan (No. 2 the Year 2011) about the management of water quality and water pollution control.

\section{Procedure}

There were Steps in the Model QUAL2Kw procedure, they were: first, doing data entry and then running the program. Second, the entry data QUAL2Kw program. The data includes the river segment, distance each segment from upstream to downstream, altitude/river elevation, coordinate segment, Point Source (PS), and Non Point Source (NPS). There were also the climatology and Hydrology data used; the climatology data includes the temperature, wind speed, cloud cover, and the hydrology data includes coefficient manning, wide river, river discharge, discharge of PS, and NPS [11]. Output results could be viewed in two ways, using the graphs and tables. The output table could be seen on the worksheet WQ Output, while the output graph could be seen on the spatial chart worksheet [12].

The other steps were the calibration and validation of the simulations. The method used was the trial and error model. It included the use of the addition and subtraction of pollution load on the parameters, so the examination of the study will fit the scenario created. The operation of the model was done separately. The pollution load was calculated based on the approach to land use. Land use in the Karang Mumus watershed was dominated by $43.86 \%$ settlements and estates $25.42 \%$. Pollution load was calculated by reduction value in scenario II (pollution load capacity) and scenario I (pollution load in the existing condition). The minus result (-) indicates that the pollution load has exceeded capacity and must be reduced. Conversely, if the result is positive (+), it indicates that the capacity still holds the burden of pollution. The output of the program was the magnitude maximum pollution load capable accepted the river [12]. 


\section{- RESULTS AND DISCUSSION}

Pollution load capacity is the maximum amount of pollution loads allowed to be dumped into the water body without causing pollution. Then, the allocation of the burden of pollution is pollution load that can still be accommodated. Analysis of Point Source (PS) and Non Point Source (NPS) pollutants were used to calculate pollution loads. Tributaries and drainage that entered the main river (Sub DAS B2-B11) as PS and were added with NPS calculated from the land use approach. The map of land use and distribution of pollution sources of Karang Mumus watershed were presented in Fig. 2. The land use in Karang Mumus watershed was predominantly residential in the downstream as it is the location of the center of Samarinda City, East Kalimantan Province. Potential pollutant sources in each segment were presented in Table 2.

The settlements have the highest potential of being a polluting source in Karang Mumus River. It was in accordance with the percentage of land use in Karang Mumus watershed 43.86 of settlement and the city in the downstream area. The water quality of the Karang Mumus River decreased due to pollution. High Fe, Mn, COD, and TSS content in river water were affected by industrial waste, domestic waste, agriculture, and urban area runoff [13]. River water quality with urban land use indicated that water quality was physically polluted and was not suitable for consumption [4]. Fig. 3 presents an overview of the area around Karang Mumus River.

\section{Pollution Load of BOD, COD, and TSS in Karang Mumus River}

The pollution load analysis was done on each segment of the rivers, and it was originated from domestic activity, trash, livestock, agriculture, and building. The analysis of BOD, COD, and TSS are presented in Table 3, 4, and 5 .

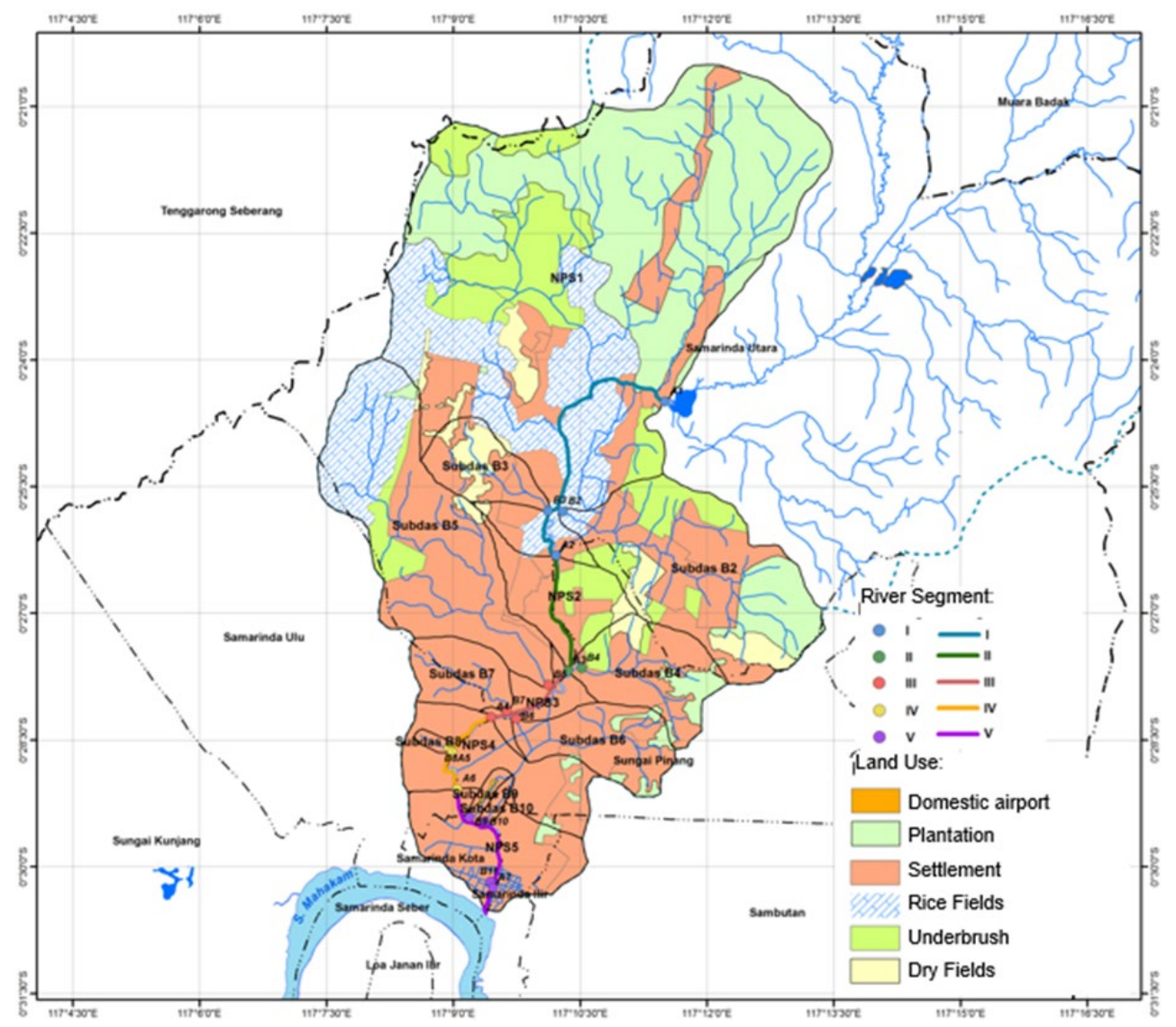

Fig 2. Land use and distribution of pollution source 
Table 2. Potential pollutant sources each river segment

\begin{tabular}{|c|c|c|c|c|c|c|}
\hline No. & Location & Code & Segment & $\begin{array}{l}\text { Sub- } \\
\text { District }\end{array}$ & $\begin{array}{l}\text { Pollutant } \\
\text { Source }\end{array}$ & Potential of Pollutant Source \\
\hline 1 & $\begin{array}{l}\text { Bridge after Benanga } \\
\text { Reservoir }\end{array}$ & A1 & \multirow{4}{*}{ I } & \multirow{4}{*}{$\begin{array}{l}\text { Samarinda } \\
\text { Utara }\end{array}$} & NPS 1 & Upstream activity \\
\hline 2 & Lempake Jaya River & B2 & & & Sub DAS B2 & Settlement \\
\hline 3 & Bengkuring River & B3 & & & Sub DAS B3 & $\begin{array}{l}\text { Bengkuring Residence, Traditional } \\
\text { Bengkuring Market, Loundry }\end{array}$ \\
\hline 4 & Tepian Lempake Bridge & $\mathrm{A} 2$ & & & & \\
\hline 5 & Mugirejo-Gn. Lingai River & B4 & \multirow{2}{*}{ II } & \multirow{2}{*}{$\begin{array}{l}\text { Sungai } \\
\text { Pinang }\end{array}$} & Sub DAS B4 & \multirow[t]{2}{*}{$\begin{array}{l}\text { Citra land Residence, Mugirejo } \\
\text { Residence, Loundry }\end{array}$} \\
\hline 6 & $\begin{array}{l}\text { Gunung Lingai (P.M. } \\
\text { Noor Street) }\end{array}$ & $\mathrm{A} 3$ & & & NPS 2 & \\
\hline 7 & Sempaja River & B5 & \multirow{4}{*}{ III } & \multirow{4}{*}{$\begin{array}{l}\text { Sungai } \\
\text { Pinang } \\
\text { and } \\
\text { Samarinda } \\
\text { Utara }\end{array}$} & Sub DAS B5 & $\begin{array}{l}\text { Pondok Surya Indah Residence, Rapak } \\
\text { Binuang Drainage, TVRI Drainage, } \\
\text { Pinang Mas Drainage, Loundry }\end{array}$ \\
\hline 8 & $\begin{array}{l}\text { A. Yani (Gelatik-Pemuda) } \\
\text { Drainage }\end{array}$ & B6 & & & Sub DAS B6 & $\begin{array}{l}\text { The settlement around A. Yani Street, } \\
\text { Pemuda Street, Sentosa Street, Hotel } \\
\text { Grand Violand, Hotel Crystal }\end{array}$ \\
\hline 9 & Pramuka-UNMUL River & B7 & & & Sub DAS B7 & $\begin{array}{l}\text { The settlement around Pramuka Street, } \\
\text { Loundry }\end{array}$ \\
\hline 10 & Gelatik Bridge & A4 & & & NPS 3 & \\
\hline 11 & $\begin{array}{l}\text { Lembuswana-Vorvoo } \\
\text { Drainage }\end{array}$ & B8 & \multirow{3}{*}{ IV } & \multirow{3}{*}{$\begin{array}{l}\text { Samarinda } \\
\text { Ulu }\end{array}$} & \multirow{3}{*}{$\begin{array}{l}\text { Sub DAS B8 } \\
\text { NPS } 4\end{array}$} & $\begin{array}{l}\text { Mall Lebuswana, Mall Samarinda Square, } \\
\text { Hotel Grand Victory, Settlements around } \\
\text { Voorvo }\end{array}$ \\
\hline 12 & S. Parman Bridge & A5 & & & & \multirow[b]{2}{*}{$\begin{array}{l}\text { Centre Market Segiri, settlements in river } \\
\text { bank }\end{array}$} \\
\hline 13 & Perniagaan Bridge & A6 & & & & \\
\hline 14 & $\begin{array}{l}\text { Gatot Subroto Street } \\
\text { Drainage }\end{array}$ & B9 & \multirow{3}{*}{$\mathrm{V}$} & \multirow{3}{*}{$\begin{array}{l}\text { Samarinda } \\
\text { Kota and } \\
\text { Samarinda } \\
\text { Ilir }\end{array}$} & Sub DAS B9 & $\begin{array}{l}\text { Settlements around Gatot Subroto Street, } \\
\text { Hotel Dragon, }\end{array}$ \\
\hline 15 & $\begin{array}{l}\text { Lambung Mangkurat } \\
\text { Street Drainage }\end{array}$ & B10 & & & Sub DAS B10 & $\begin{array}{l}\text { Settlements around Lambung Mangkurat } \\
\text { Street, Hotel Diamond, Traditional } \\
\text { Lambung Mangkurat Market, }\end{array}$ \\
\hline 16 & P. Hidayatullah Drainage & B11 & & & Sub DAS B11 & $\begin{array}{l}\text { Settlements around Hidayatullah Street, } \\
\text { Mall SCP, Hotel ASTON, Hotel Borneo } \\
\text { Swiss Bell }\end{array}$ \\
\hline 17 & Sei Dama Bridge & A7 & & & NPS 5 & \\
\hline
\end{tabular}

A = Main River/Karang Mumus River;

$\mathrm{B}=$ Tributary and Drainage

Sub DAS B2-B11 are PS

Table 3. BOD pollution load

\begin{tabular}{lcccccc}
\hline \multirow{2}{*}{ River Segment } & \multicolumn{5}{c}{ BOD Pollution Load (kg/day) } \\
\cline { 2 - 6 } & Domestic & Trash & Livestock & Agriculture & Building & Total \\
\hline Segment 1 & 371.71 & 3.14 & 25.79 & 415.89 & - & 816.53 \\
Segment 2 & 536.29 & 4.54 & 18.05 & 30.85 & - & 589.73 \\
Segment 3 & 982.28 & 8.31 & 34.24 & 81.69 & - & $1,106.53$ \\
Segment 4 & 891.02 & 7.54 & 11.93 & 0.39 & - & 910.87 \\
Segment 5 & $2,905.46$ & 24.58 & 1.13 & 0.21 & 1.12 & $2,932.49$ \\
Total & $5,686.75$ & 48.11 & 91.14 & 529.03 & 1.12 & $6,356.15$ \\
Percentage & 89.47 & 0.76 & 1.43 & 8.32 & 0.02 & 100.00 \\
\hline
\end{tabular}




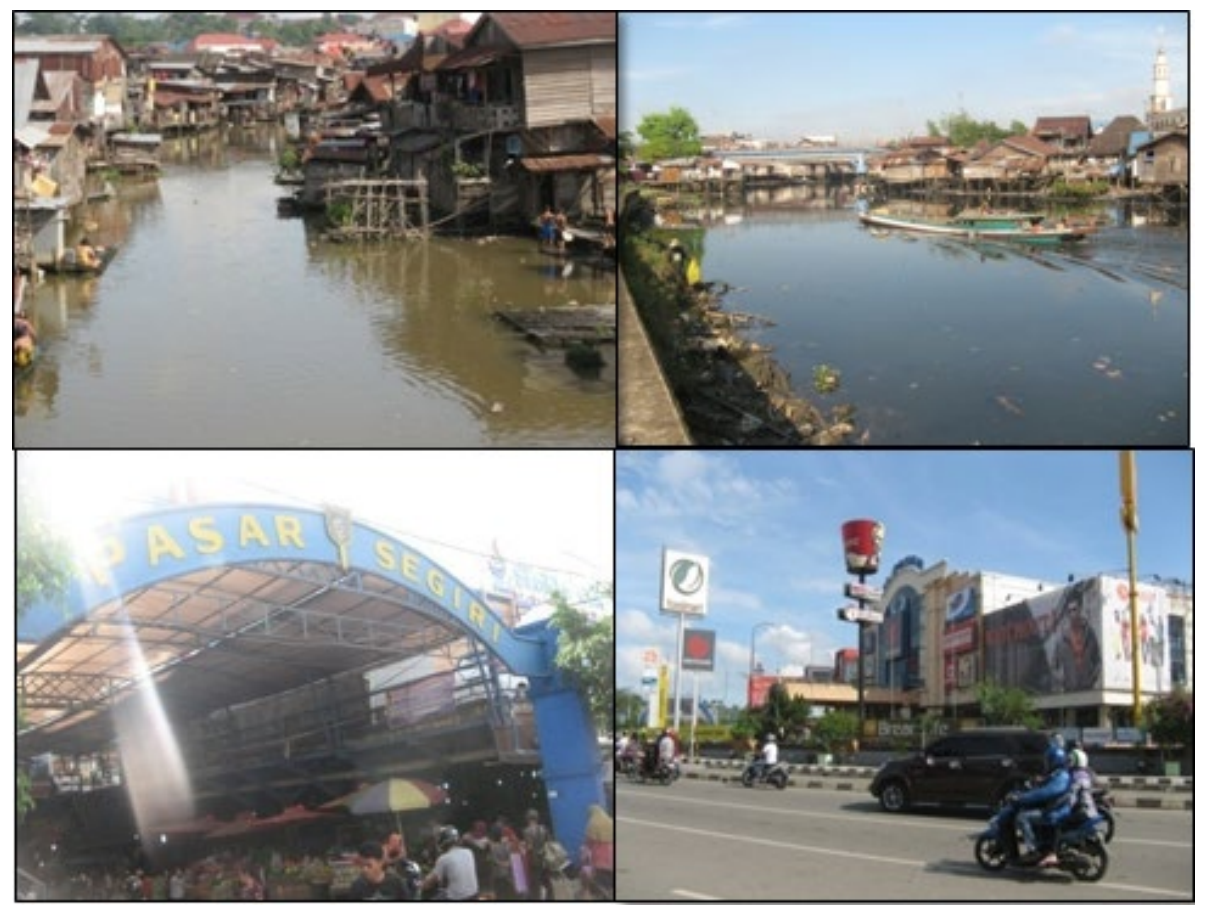

Fig 3. Overview of the area around Karang Mumus River

Table 4. COD pollution load

\begin{tabular}{lcrcccr}
\hline \multirow{2}{*}{ River Segment } & \multicolumn{7}{c}{ COD Pollution Load (kg/day) } \\
\cline { 2 - 7 } & Domestic & Trash & Livestock & Agriculture & Building & \multicolumn{1}{c}{ Total } \\
\hline Segment 1 & 511.10 & 4.32 & 61.92 & 623.83 & - & $1,201.17$ \\
Segment 2 & 737.40 & 6.24 & 43.19 & 46.27 & - & 833.09 \\
Segment 3 & $1,350.64$ & 11.43 & 82.02 & 122.53 & - & $1,566.61$ \\
Segment 4 & $1,225.15$ & 10.36 & 28.49 & 0.59 & - & $1,264.59$ \\
Segment 5 & $3,995.00$ & 33.80 & 4.02 & 0.32 & 1.67 & $4,034.81$ \\
Total & $7,819.28$ & 66.15 & 219.63 & 793.55 & 1.67 & $8,900.28$ \\
Percentage & 87.85 & 0.74 & 2.47 & 8.92 & 0.02 & 100.00 \\
\hline
\end{tabular}

Table 5. TSS pollution load

\begin{tabular}{lcrcccr}
\hline \multirow{2}{*}{ River Segment } & \multicolumn{7}{c}{ TSS Pollution Load (kg/day) } \\
\cline { 2 - 7 } & Domestic & Trash & Livestock & Agriculture & Building & Total \\
\hline Segment 1 & 353.12 & 2.99 & 22.38 & 3.36 & - & 381.84 \\
Segment 2 & 509.47 & 4.31 & 15.49 & 0.14 & - & 529.41 \\
Segment 3 & 933.17 & 7.89 & 29.49 & 0.22 & - & 970.78 \\
Segment 4 & 846.46 & 7.16 & 10.19 & 0.02 & - & 863.84 \\
Segment 5 & $2,760.18$ & 23.35 & 1.44 & 0.01 & 0.56 & $2,785.54$ \\
Total & $5,402.41$ & 45.70 & 78.99 & 3.75 & 0.56 & $5,531.42$ \\
Percentage & 97.67 & 0.83 & 1.43 & 0.07 & 0.01 & 100.00 \\
\hline
\end{tabular}

The highest pollution load of BOD, COD, and TSS in all Karang Mumus River segments were originated from domestic activities. We can see from Fig. 2 that
Segment 1 and 2 were dominated by the forestry. On the other hand, segment 3 to segment 5 were dominated by the land use of settlement, including density settlement 
on the river banks. The highest pollution load of BOD, COD, and TSS was in segment 5. Urbanization and density of settlements on the river bank were contributed to the water pollution [4].

The high BOD was affected by the source of the contaminant from any famous tourist places [14]. BOD and COD were the indicators of organic pollutants sourced from agriculture and the settlement of domestic waste [15]. In the context of urbanization, many industries across the country also contributed a significant amount of PAHs (Polycyclic Aromatic Hydrocarbon). It was evidenced by the existence of organic pollutants in some rivers across Jakarta City [16].

Yet Geographically, Karang Mumus River has a little elevation in it and there is no any building floodgates that contributes the artificial aeration as the supply of oxygen of which can improve the quality of the water. In fact, the process of self-purification only occurs naturally without any aeration process because turbulence of the flow provides a supply of dissolved oxygen in the water [17].

\section{Pollution Load Capacity}

Calculation of pollution load capacity was done on segment 2, 3, and 4 only. It was because the data taken by the Model should not be influenced by backwater and also marshy areas of the river. After the measurement of discharge was done, it turned out that in segment 1 and 5 the discharge ware down on those segments. It happened because the location in segment 1 had a flat topography and the marsh area, while segment 5 was influenced by the backwater of Mahakam River. The pollution load capacity of BOD, COD, and TSS were presented in Table 6, 7, and 8.

Pollution load graphs on the existing conditions (scenario I) and pollution load capacity (scenario II) were presented in Fig. 4, 5, and 6. Zero points on the graph were upstream of Karang Mumus River. The graphs were presented for BOD, COD, and TSS parameters.

Based on Table 6, the pollution load of BOD in the entire segment exceeded the capacity. The highest allocation of the BOD pollution load in segment 4 was

Table 6. The pollution load capacity of BOD

\begin{tabular}{lrrrrrr}
\hline \multirow{2}{*}{ Segment } & \multicolumn{2}{c}{ Existing Pollution Load } & \multicolumn{2}{c}{ Pollution Load Capacity } & \multicolumn{2}{c}{ Allocation of Pollution Load } \\
\cline { 2 - 7 } & $\mathrm{mg} / \mathrm{L}$ & $\mathrm{kg} / \mathrm{day}$ & $\mathrm{mg} / \mathrm{L}$ & $\mathrm{kg} / \mathrm{day}$ & $\mathrm{mg} / \mathrm{L}$ & $\mathrm{kg} / \mathrm{day}$ \\
\hline 2 & 30.00 & 885.12 & 4.60 & 207.81 & -25.40 & -677.30 \\
3 & 67.40 & $1,323.76$ & 46.50 & 818.27 & -20.90 & -505.49 \\
4 & 168.82 & $3,941.64$ & 43.82 & 918.35 & -125.00 & $-3,023.29$ \\
Total & 266.22 & $6,150.52$ & 94.92 & $1,944.43$ & -171.30 & $-4,206.09$ \\
\hline
\end{tabular}

Table 7. The pollution load capacity of COD

\begin{tabular}{lcccrcr}
\hline \multirow{2}{*}{ Segment } & \multicolumn{2}{c}{ Existing Pollution Load } & \multicolumn{2}{c}{ Pollution Load Capacity } & \multicolumn{2}{c}{ Allocation of Pollution Load } \\
\cline { 2 - 7 } & $\mathrm{mg} / \mathrm{L}$ & $\mathrm{kg} / \mathrm{day}$ & $\mathrm{mg} / \mathrm{L}$ & $\mathrm{kg} / \mathrm{day}$ & $\mathrm{mg} / \mathrm{L}$ & $\mathrm{kg} / \mathrm{day}$ \\
\hline 2 & 184.63 & $4,836.21$ & 170.63 & $4,497.60$ & -14.00 & -338.61 \\
3 & 133.10 & $2,623.44$ & 531.10 & $12,249.59$ & 398.00 & $9,626.15$ \\
4 & 279.86 & $6,396.73$ & 199.86 & $4,461.83$ & -80.00 & $-1,934.90$ \\
Total & 597.59 & $13,856.38$ & 901.59 & $21,209.02$ & 304.00 & $7,352.64$ \\
\hline
\end{tabular}

Table 8. The pollution load capacity of TSS

\begin{tabular}{lrrrrrr}
\hline \multirow{2}{*}{ Segment } & \multicolumn{2}{c}{ Existing Pollution Load } & \multicolumn{2}{c}{ Pollution Load Capacity } & \multicolumn{2}{c}{ Allocation of Pollution Load } \\
\cline { 2 - 6 } & $\mathrm{mg} / \mathrm{L}$ & $\mathrm{kg} / \mathrm{day}$ & $\mathrm{mg} / \mathrm{L}$ & $\mathrm{kg} / \mathrm{day}$ & $\mathrm{mg} / \mathrm{L}$ & $\mathrm{kg} / \mathrm{day}$ \\
\hline 2 & 21.05 & $1,073.55$ & 418.05 & $10,442.73$ & 397.00 & $9,369.18$ \\
3 & 35.48 & 714.68 & 216.08 & $5,018.99$ & 180.60 & $4,304.31$ \\
4 & 287.93 & 373.68 & 283.73 & $6,102.93$ & -4.20 & $5,729.25$ \\
Total & 344.46 & $2,161.91$ & 917.86 & $21,564.65$ & 573.40 & $19,402.74$ \\
\hline
\end{tabular}




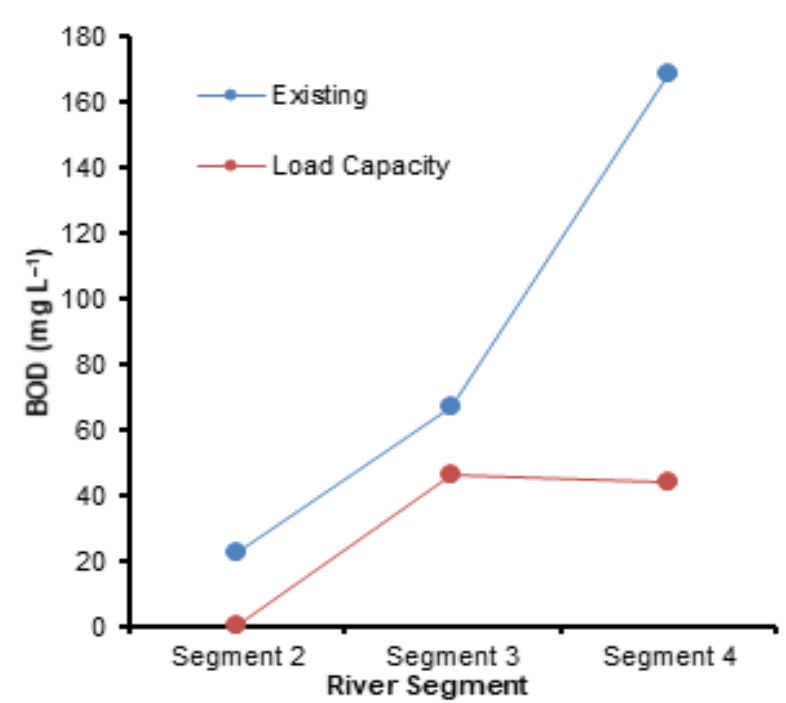

Fig 4. Pollution load capacity with the Existing condition of the BOD

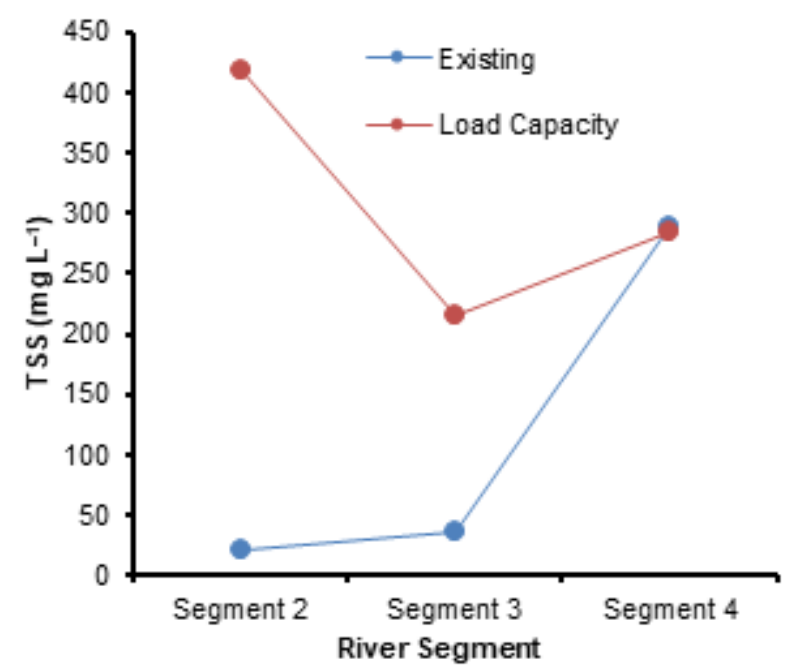

Fig 6. Pollution load capacity with the existing condition of the TSS

$-3,023.29 \mathrm{~kg} / \mathrm{day}$, and it should be taken down. It was because the dominant land use in segment 4 was a settlement of $96.43 \%$. This area is the center of Samarinda City with a density of settlement, Mall, Hospital and Traditional Market 'Segiri'. The result of the analysis BOD content in waters using QUAL2Kw concluded that the treatment to improve water quality in the location is needed. It was similar to the statements [8] that the simulation result of BOD by QUAL2Kw was used to determine location to improve water quality.

Based on Table 7, segment 3 still holds the COD pollution load of $398 \mathrm{mg} / \mathrm{L}$ with land use of settlement

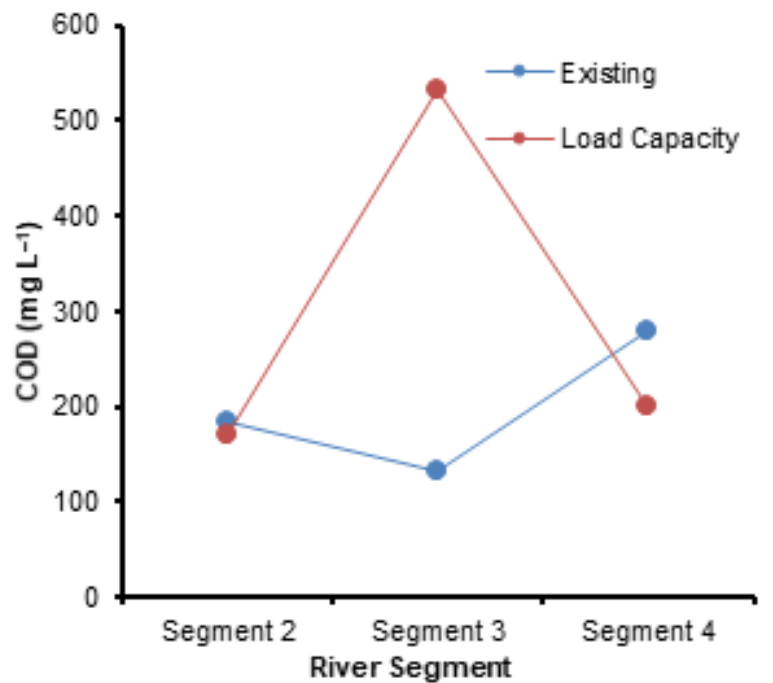

Fig 5. Pollution load capacity with the existing condition of the COD

71.11\%. Segment 2 and 4 have COD pollution load exceeding capacity with the allocation of pollution load that must be reduced by $14 \mathrm{mg} / \mathrm{L}$ and $80 \mathrm{mg} / \mathrm{L}$. The land use for settlement in segment 2 of $67.22 \%$, and there were small 'tempeh' industries. Segment 4 has the highest COD pollution load is $279.86 \mathrm{mg} / \mathrm{L}$. It was because of the influence of dominant land use settlement of $96.43 \%$. This area is the center of Samarinda City density settlements, Mall, Hospital, and Big Market 'Segiri". A lot of residential settlements in riverbank with residents' daily activities such as bath, washing, and toilet to the river. It affected COD content because of the many organic compounds degraded in the water.

Based on Table 8, The TSS pollution load across the segment of the river still met the capacity. The pollution load of TSS in segment 4 was approaching capacity. It made sense because there are shopping malls/shopping centers, density residential, hotel, and hospital. TSS compound affected by runoff from the rainwater. The concentration of pollutants in the river is influenced by storm characteristic runoff and land uses [18]. Pollution load capacity for BOD, COD, and TSS was influenced by pollution load coming from the waste of community activities in settlements; it was necessary to be supervised [19].

The map of the capacity of pollution load BOD, COD and TSS presented in Fig. 7 showed the spatial 

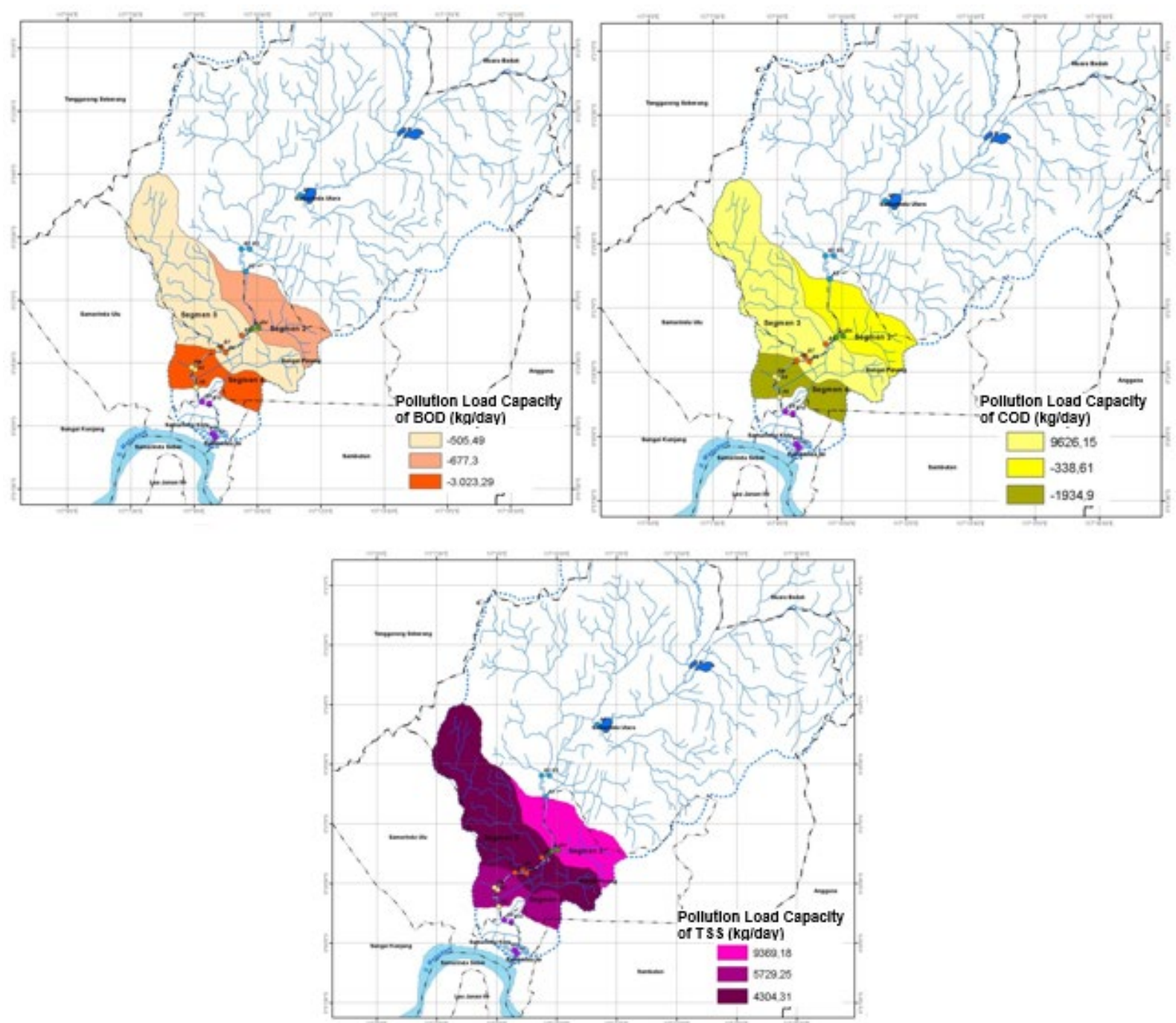

Fig 7. Spatial distribution of pollution load capacity for BOD, COD, and TSS

distribution of the pollution load capacity in the Karang Mumus watershed.

\section{Allocation of Pollution Load}

Allocation of sector pollution load for BOD, COD, and TSS were presented in Table 9, 10, and 11. It was calculated based on land use percentage in Karang Mumus watershed.

Based on Table 9, the highest allocation sector of pollution load for BOD were originated from the domestic activity from settlements. The highest domestic sector of the BOD pollution load that must be reduced is $-2,957.37 \mathrm{~kg} /$ day in segment 4 , with the dominant land use settlement of $96.43 \%$.
Based on Table 10, the highest allocation sector of pollution load for COD was from the domestic sector. The highest domestic sector of COD pollution load that must be reduced is $-1,874.55 \mathrm{~kg} /$ day in segment 4 , with dominant land use settlement of $96.43 \%$. Segment 3 was still capable of accommodating COD of $8,299.08 \mathrm{~kg} / \mathrm{day}$ of the domestic sector. Settlements in segment 3 of $71.11 \%$ were smaller than segment 4 . The allocation sector of pollution load for COD should be reduced in segment 2 is $-299.71 \mathrm{~kg} /$ day with land use $67.22 \%$. There were small 'tempeh' industries in segment 2, thus causing the pollution load of COD exceeding the capacity, although having the smallest settlement compared to segment 3 and 4 . 
Table 9. Allocation of sector pollution load for BOD

\begin{tabular}{|c|c|c|c|c|c|c|}
\hline \multirow{2}{*}{ Segment } & \multicolumn{5}{|c|}{ Allocation of Sector Pollution Load (kg/day) } & \multirow{2}{*}{ Total } \\
\hline & Domestic & Trash & Livestock & Agriculture & Building & \\
\hline 2 & -615.93 & -5.21 & -20.74 & -35.43 & 0.00 & -677.30 \\
\hline 3 & -448.74 & -3.80 & -15.64 & -37.32 & 0.00 & -505.49 \\
\hline 4 & $-2,957.37$ & -25.02 & -39.58 & -1.31 & 0.00 & $-3,023.29$ \\
\hline Total & $-4,022.04$ & -34.03 & -75.96 & -74.06 & 0.00 & $-4,206.09$ \\
\hline
\end{tabular}

(-) indicates the pollution load must be reduced

Table 10. Allocation of sector pollution load for COD

\begin{tabular}{|c|c|c|c|c|c|c|}
\hline \multirow{2}{*}{ Segment } & \multicolumn{5}{|c|}{ Allocation of Sector Pollution Load (kg/day) } & \multirow{2}{*}{ Total } \\
\hline & Domestic & Trash & Livestock & Agriculture & Building & \\
\hline 2 & -299.71 & -2.54 & -17.55 & -18.81 & 0.00 & -338.61 \\
\hline 3 & $8,299.08$ & 70.21 & 503.96 & 752.90 & 0.00 & $9,626.15$ \\
\hline 4 & $-1,874.55$ & -15.86 & -43.59 & -0.91 & 0.00 & $-1,934.90$ \\
\hline Total & $6,124.82$ & 51.82 & 442.82 & 733.18 & 0.00 & $7,352.64$ \\
\hline
\end{tabular}

(-) indicates the pollution load must be reduced

Table 11. Allocation of sector pollution load for TSS

\begin{tabular}{crrrrrr}
\hline \multirow{2}{*}{ Segment } & \multicolumn{7}{c}{ Allocation of Sector Pollution Load (kg/day) } & \multirow{2}{*}{ Total } \\
\cline { 2 - 6 } & Domestic & Trash & Livestock & Agriculture & Building & $9,369.18$ \\
2 & $9,016.31$ & 76.28 & 274.12 & 2.48 & - & $4,304.31$ \\
3 & $4,137.54$ & 35.00 & 130.77 & 0.99 & - & $5,729.25$ \\
4 & $5,614.02$ & 47.49 & 67.60 & 0.13 & - & - \\
Total & $18,767.87$ & 343.18 & $1,853.82$ & 210.81 & -972.41 \\
\hline
\end{tabular}

Based on Table 11, the highest allocation sector of pollution load came from the domestic activity for segment 2, 3 and 4 . The whole segment was still capable of holding TSS pollution load, the highest in segment 2 of $9,016.31 \mathrm{~kg} /$ day and lowest in segment 3 of $4,137.54 \mathrm{~kg} /$ day. It was due to the measurement was conducted at a time when the rain did not occur.

Similar to the statement of Baherem et al. [19], the pollution load capacity of BOD, COD, and TSS sources are originated from the waste of community activities in settlements. It means that public awareness and participation are not adequate to save the river from pollutants. Cooperation between stakeholder and communities are needed to manage bank erosion and agricultural practices aiming to minimize soil erosion in the catchment and sediment input to the river [20].

Based on the spatial distribution of pollution load capacity analysis, we can see more detailed information about the location that needs to be considered by the government as an effort to manage the environment. In addition, the calculation of sector pollution load allocation provided information about the dominant pollutant source. It can help the government efforts to control water pollution from the source. Hence, the collaboration involving all stakeholder are needed to develop a good river management especially for the communities who lives around the river to always maintain and improve river water quality [21].

\section{- CONCLUSION}

The urban areas with the predominantly residential land have potential high pollution load to parameters of BOD, COD, and TSS. Karang Mumus River segment 2, 3 and 4 have a BOD capacity exceeded. Segment 3 was still capable of accommodating COD, and segment 2, 3 and 4 still holds the TSS.

\section{- ACKNOWLEDGMENTS}

Loads of Thank for the Environment Government of Samarinda City, River Area Mahakam-Berau Government who gave the secondary data. Thanks to Mr. Agus, Mr. Irwan, Mr. Hardi, Mrs. Yuli and the team 
who helped to measurement and collect data in the field. Thanks for Health Laboratory Samarinda Province for helping the measurement of the laboratory test. Finally, thanks a lot for Kemenristek Dikti, which granted the funding to do this research, with the contract number of 124/SP2H/PPM/DRPM/IV/2017.

\section{- REFERENCES}

[1] Patang, F., Soegianto, A., and Hariyanto, S., 2018, Benthic macroinvertebrates diversity as bioindicator of water quality of some rivers in east Kalimantan, Indonesia, Int. J. Ecol., 2018, 5129421.

[2] Hadibarata, T., Syafiuddin, A., and Ghfar, A.A., 2019, Abudance and distribution of polycyclic aromatic hydrocarbon (PAHs) in sediments of the Mahakam River, Mar. Pollut. Bull., 149, 110650.

[3] Effendy, H., 2016, River Water quality preliminary rapid assessment using pollution index, Procedia Environ. Sci., 33, 562-567.

[4] Kalavaty, S., Sharma, T.R., and Sureshkumar, P., 2011, Water quality index of river Cauvery in Tiruchirappalli district, Tamilnadu, Arch. Environ. Sci., 5, 55-61.

[5] Lai, Y.C., Yang, C.P., Hsieh, C.Y., Wu, C.Y., and Kao, C.M., 2011, Evaluation of non-point source pollution and river water quality using a multimedia twomodel system, J. Hydrol., 409 (3-4), 583-595.

[6] Yadav, S.S., and Rajesh, K., 2011, Monitoring water quality of Kosi river in Rampur district, Uttar Pradesh, India, Adv. Appl. Sci. Res., 2 (2), 197-201.

[7] Kannel, P.R., Lee, S., Lee, Y.S., Kanel, S.R., and Pelletier, G.J., 2007, Application of automated QUAL2Kw for water quality modeling and management in the Bagmati river, Nepal, Ecol. Modell., 202 (3-4), 503-517.

[8] Farhadian, M., Bozorg-Haddad, O., Pazoki, M., and Loaiciga, H.A., 2019, Minimal adverse impact of discharging polluted effluents to rivers with selective location, Sustain. Cities Soc., 46, 101394.

[9] Gikas, G.D., 2014, Water quality of drainage canals and assessment of nutrient load using QUAL2Kw, Environ. Processes, 1 (4), 369-385.

[10] Sharma, D., Kansal, A., and Pelletier, G., 2015, Water quality modeling for urban reach of Yahuma river,
India (1999-2009), using QUAL2Kw, Appl. Water Sci., 7 (3), 1535-1559.

[11] Pelletier, G.J., and Chapra, S.C., 2008, QUAL2Kw theory and documentation (version 5.1): A modeling framework for simulating river and stream water quality, Environmental Assessment Program, Department of Ecology, Olympia, Washington.

[12] Pelletier, G.J., and Chapra, S.C., 2008, QUAL2Kw user manual (version 5.1): A modeling framework for simulating river and stream water quality, Environmental Assessment Program, Department of Ecology, Olympia, Washington.

[13] Yisa, J., and Jimoh, T., 2010, Analytical studies on water quality index of river Landzu, Am. J. Appl. Sci., 7 (4), 453-458.

[14] Kumar, A., Bisht, B.S., Joshi, V.D., Singh, A.K., and Talwar, A., 2010, Physical, chemical and bacteriological study of water from rivers of Uttarakhand, J. Hum. Ecol., 32 (3), 169-173.

[15] Venkatesharaju, K., Ravikumar, P., Somashekar, R.K., and Prakash, K.L., 2010, Physico-chemical and bacteriological investigation on the river Cauvery of Kollegal stretch in Karnataka, Kathmandu Univ. J. Sci. Eng. Technol., 6 (1), 50-59.

[16] Rinawati, and Takada, H., 2017, Distribution and source of sedimentary Polycyclic Aromatic Hydrocarbon (PAHs) in river sediment of Jakarta, Indones. J. Chem., 17 (3), 394-400.

[17] Arbie, R.R., Nugraha, W.D., and Sudarno, 2015, Studi kemampuan self purification pada sungai Progo ditinjau dari parameter organik DO dan BOD, Jurnal Teknik Lingkungan, 4 (3), 1-15.

[18] Chow, M.F., Yusop, Z., and Shirazi, S.M., 2013, Storm runoff and pollutant loading ffrom commercial, residential and industrial catchments in the tropic, Environ. Monit. Assess., 185 (10), 8321-8331.

[19] Baherem, Suprihatin, and Indrasti, N.S., 2014, Strategi pengelolaan sungai Cibanten provinsi Banten berdasarkan analisis daya tampung beban pencemaran air dan kapasitas asimilasi, JPSL, 4 (1), 60-69.

[20] Hartwig, M., Schäffer, M., Theuring, P., Avlyush, S., M. Rode, M., and Borchardt, D., 2016, Cause-effect- 
response chain linking source identification of eroded sediments, loss of aquatic ecosystem integrity and management options in a steppe river catchment (Khaara, Mongolia), Environ. Earth Sci., 75 (10), 855.
[21] Endayani, S., Sadono, R., Kusumandari, A., and Hartono, 2019, Social and economic vulnerability in the sub-watershed of Karang Mumus, East Kalimantan Province, JMHT, 25 (2), 93-103. 